\title{
Seagrass response following exposure to Deepwater Horizon oil in the Chandeleur Islands, Louisiana (USA)
}

\section{W. Judson Kenworthy ${ }^{1,2, *}$, Natalie Cosentino-Manning ${ }^{3}$, Lawrence Handley ${ }^{4}$ Michael Wild ${ }^{5}$, Shahrokh Rouhani ${ }^{5}$}

\author{
${ }^{1}$ Industrial Economics Inc, 109 Holly Lane, Beaufort, NC 28516, USA \\ ${ }^{2}$ Center for Coastal Fisheries and Habitat Research, NCCOS, NOS, NOAA, 101 Pivers Island Rd, Beaufort, NC 28516, USA \\ ${ }^{3}$ National Oceanic and Atmospheric Administration, Fisheries Restoration Center, 777 Sonoma Avenue, Santa Rosa, \\ CA 95404, USA \\ ${ }^{4}$ Industrial Economics Inc., 14 Kingshighway, Eureka Springs, AR 76232, USA \\ ${ }^{5}$ NewFields Companies, LLC, 1349 W. Peachtree Street, Suite 2000, Atlanta, GA 30309, USA
}

\begin{abstract}
The Chandeleur Islands, Louisiana (USA), were among the first coastal locations in the northern Gulf of Mexico (GoM) threatened by exposure to Deepwater Horizon oil. Shoreline oiling data and surface oil trajectories (aerial and satellite imagery) showed oil passing through seagrass beds on the shallow back barrier shelf west of the islands repeatedly between May and early July 2010. Aerial photos in May 2010 revealed a heterogeneous distribution of surface oil crossing the shelf, and MC252 exposure was confirmed in sediments and seagrass tissue during field assessments. We observed 5 seagrasses growing at densities comparable to other northern GoM communities. Ruppia maritima and Halodule wrightii were the most common, followed by Thalassia testudinum. Syringodium filiforme and Halophila engelmannii were rarely encountered. The subtidal and intertidal seascape on the shelf was a mosaic of seagrass patches distributed in varying sizes among unvegetated and sparsely vegetated areas at water depths and in sediment types known to support seagrasses. To quantitatively assess the seagrass response following exposure, sophisticated change detection methodologies were applied to aerial photography acquired in October 2010, 2011, and 2012 in a subsample of 5 locations on the shelf where Deepwater Horizon oil exposure was confirmed. The analysis conservatively estimated a seagrass loss of 104.22 acres (42.18 ha) at these locations. Unexpectedly, the whole back barrier shelf experienced a net gain of 228 acres (92.27 ha) of seagrass between 2010 and 2011, representing a pause in the long-standing trend in seagrass declines in the Chandeleurs and indicating that oil exposure did not result in a shelf-wide catastrophe for seagrasses. Predictions for the impending disappearance of this seagrass resource in the near future may need to be reconsidered.
\end{abstract}

KEY WORDS: Oil spill · Gulf of Mexico $\cdot$ Seagrass communities $\cdot$ Change detection

\section{INTRODUCTION}

The shallow coastal waters of the northern Gulf of Mexico (GoM) are ecologically important habitats for fish, shellfish, and wildlife that provide highly valued recreational, economic, and aesthetic services to society. Seagrasses are among several coastal habitats

*Corresponding author: jud.kenworthy@gmail.com

${ }^{\S}$ Advance View was available online February 7, 2017

$\S \S$ Corrections were made after publication. For details see www.int-res.com/abstracts/meps/v576/c_p145-161/ This corrected version: August 7, 2017 that contribute to attaining these values by providing a wide range of ecological services (Michot \& Chadwick 1994, Beck et al. 2001, Duarte et al. 2005, Larkum et al. 2006, Orth et al. 2006b, Waycott et al. 2009, Barbier et al. 2011). In the northern GoM, 6 seagrass species are widely distributed along the coastlines in lagoons, bays, and barrier islands from

(C) The authors 2017. Open Access under Creative Commons by Attribution Licence. Use, distribution and reproduction are unrestricted. Authors and original publication must be credited.

Publisher: Inter-Research · www.int-res.com 
Texas to the panhandle region of northwest Florida (Green \& Short 2003, Handley et al. 2007, Ray et al. 2014). They grow in water depths ranging from the intertidal to $10 \mathrm{~m}$, but water clarity generally limits their growth to $\leq 2.0 \mathrm{~m}$ in nearshore waters, making them especially vulnerable to anthropogenic disturbances, including degraded environmental quality (Orth et al. 2006b, Waycott et al. 2009) and exposure to oil (Zieman et al. 1984). Seagrasses are considered 'ecological engineers' (van der Heide et al. 2012) because their leaf canopies baffle water flow and wave energy, and belowground rhizome and root structures bind and stabilize substrates (Fonseca et al. 1983, Fonseca \& Bell 1998, Duarte \& Chiscano 1999). These attributes promote the deposition and retention of sediments, organic matter, and other materials within the meadows and are widely cited as some of the major functions of seagrass beds (Larkum et al. 2006). However, these important functions may also be an 'Achilles heel' in an oil spill. In shallow water and intertidal areas, seagrass canopies can extend well up into the water column, sometimes even to the water surface, where they can come into direct contact with oil, weathered petroleum, and dispersants during a spill. At the same time, sea- grasses can promote the deposition of contaminants associated with suspended sediments and organic matter. Once these contaminated materials are deposited, they are not easily resuspended or transported out of the meadows, and are likely to be retained and concentrated in the leaf canopy and sediments where important bio-physical processes can become exposed to toxic chemicals.

Following the Deepwater Horizon (DWH) explosion on 20 April 2010, Macondo oil from the Mississippi Canyon Block 252 (MC252) traveled upward from the wellhead through the $1.5 \mathrm{~km}$ water column to form expansive surface oil slicks which were transported to nearshore coastal ecosystems by wind and currents (Peterson et al. 2012). Synthetic Aperture Radar (SAR) detection of surface oil (Graettinger et al. 2015) and shoreline surveys (Michel et al. 2013) demonstrated light to heavy oiling events in nearshore environments as far west as Atchafalaya Bay, Louisiana (LA), and as far east as Apalachicola, Florida (FL) (Fig. 1). Some shorelines were repeatedly oiled during the spill and long after the wellhead was capped, as early as 3 May 2010 (Michel et al. 2013) and as late as 26 July 2010 (http://gomex. erma.noaa.gov/erma.html; Daily Integrated Oil Cover).

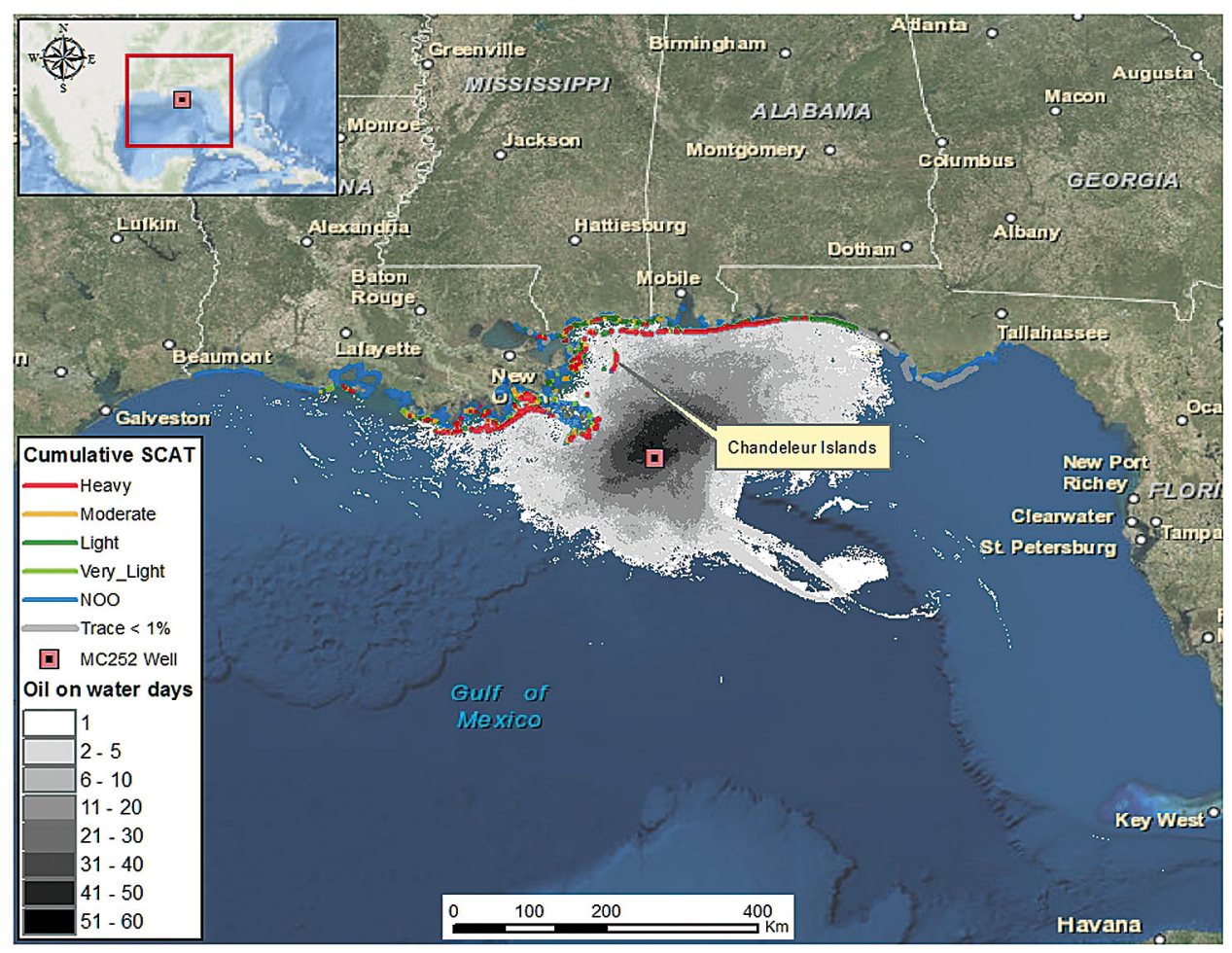

Fig. 1. Location of the Chandeleur Islands, Louisiana, USA, in the northern Gulf of Mexico $\left(29.84^{\circ} \mathrm{N}, 88.84^{\circ} \mathrm{W}\right)$, showing the estimated number of days that oil (MC252) from the Deepwater Horizon spill remained on the water surface (based on Synthetic Aperture Radar satellite imagery) and extent of cumulative shoreline oiling (assessed by the Shoreline Cleanup Assessment Technique, SCAT). NOO: no oil 
In early May 2010, oil began reaching ecologically sensitive shallow coastal habitats in the northern GoM known to have seagrasses, including the offshore barrier islands of LA (Handley et al. 2007) (Fig. 1).

The Chandeleur Islands, LA, were among the earliest locations where seagrass meadows were oiled. Evidence based on direct observations of shoreline oiling by the Shoreline Cleanup Assessment Technique (SCAT) in early May 2010 (Michel et al. 2013) confirmed oiling along a large portion of the western shoreline and fringing marshes of the Chandeleurs (Fig. 2). Oiling of the Chandeleur Islands was confirmed by SCAT surveys as early as 8 May 2010, and oil on water was clearly visible in imagery from the National Agriculture Imagery Program (NAIP) from 10 May 2010 (Fig. 3). Light to heavy oiling was
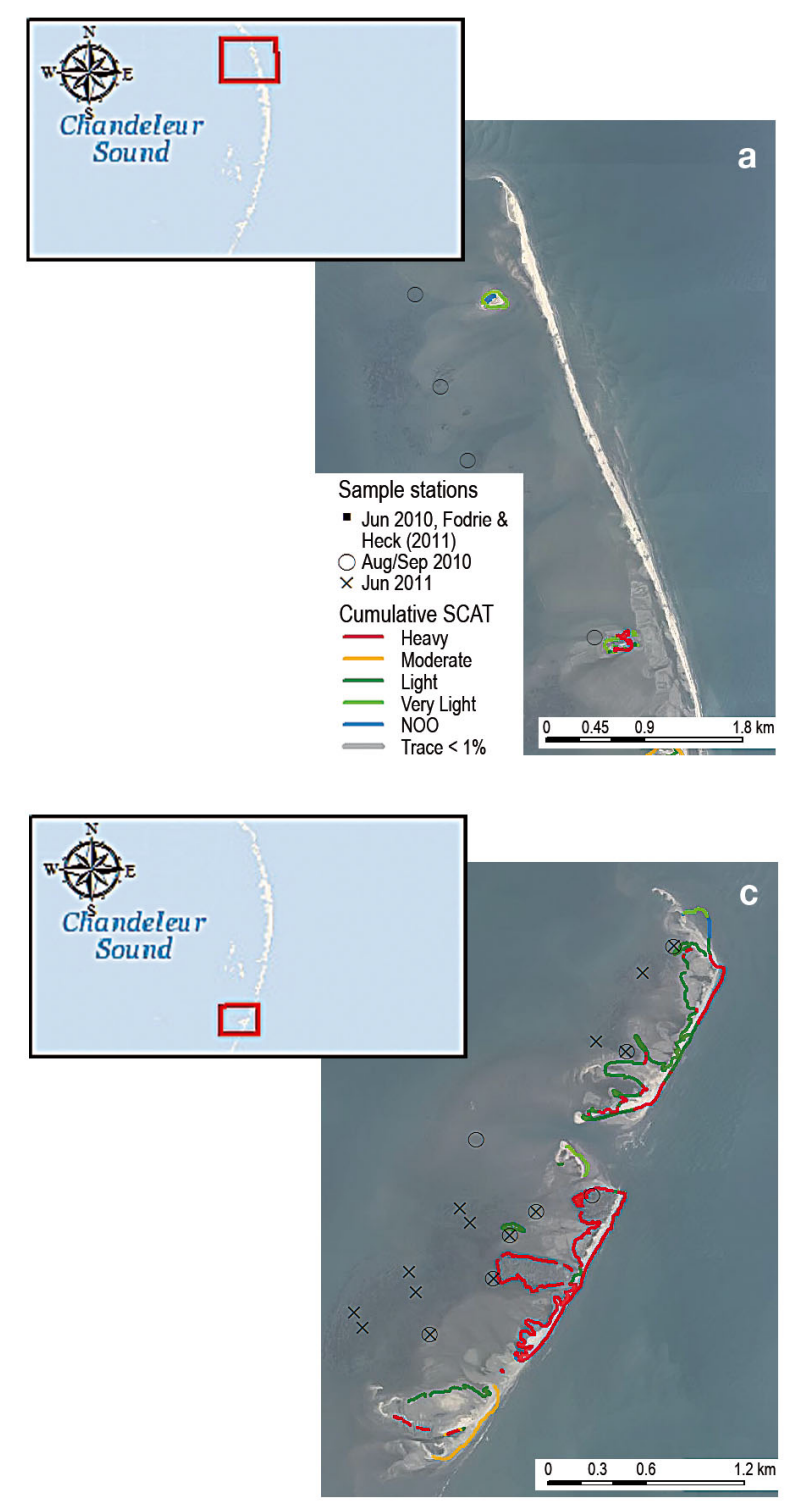

C

Fig. 2. Aerial photographs of the Chandeleur Islands showing the locations of sampling stations in August/September 2010 and June 2011, as well as the stations sampled by Fodrie \& Heck (2011) in June 2010. Also shown are the cumulative shoreline oiling data (assessed by the Shoreline Cleanup Assessment Technique, SCAT). (a) Northern (nonoiled) region, (b) central (moderately oiled), and (c) southern (heavily oiled) region. NOO: no oil 

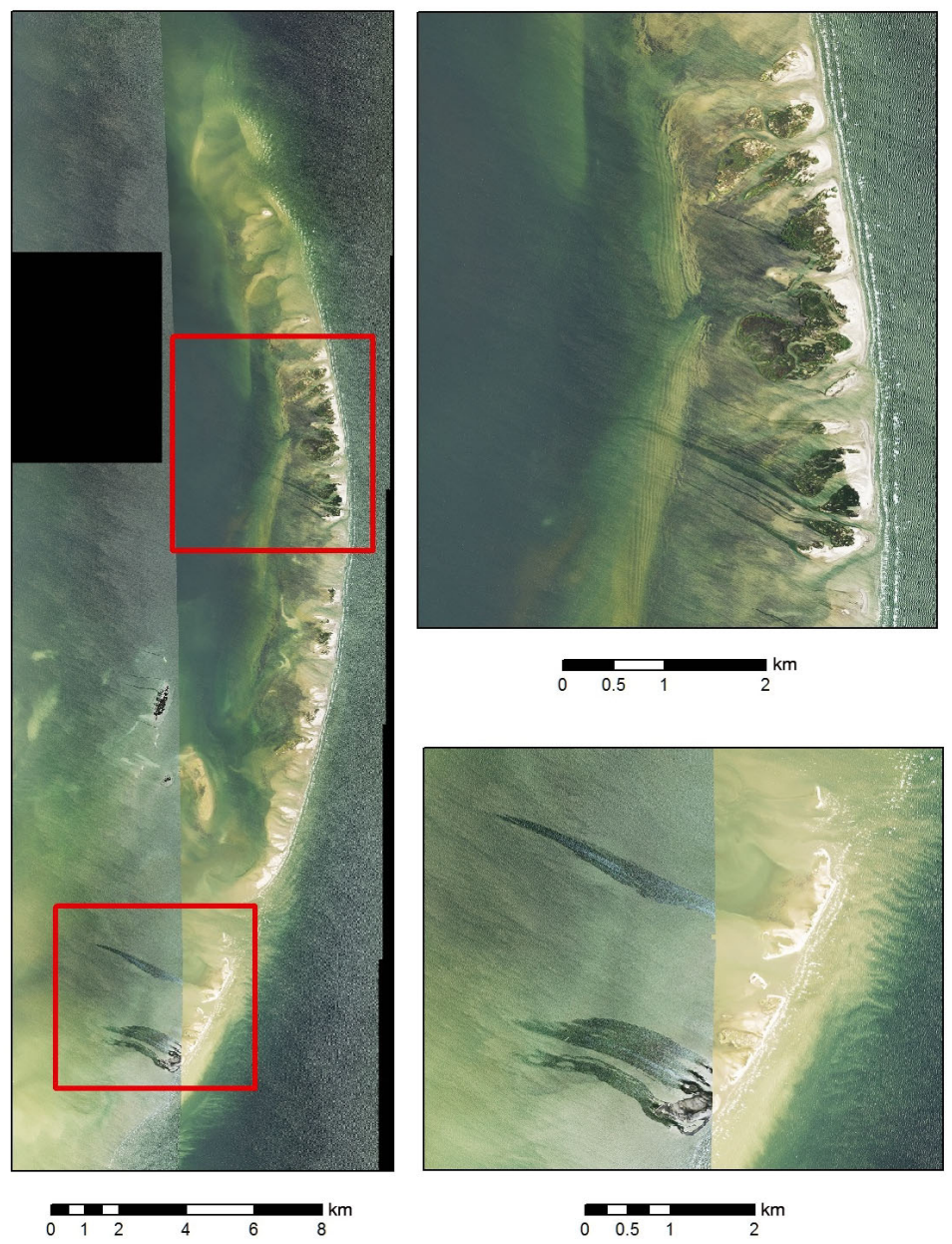

Fig. 3. National Agriculture Inventory Program (NAIP) aerial photographs taken in May 2010 showing surface sheens of oil on water in the central and southern regions of the Chandeleur Islands. Areas in the red squares are enlarged in the panels to the right

ondary impacts also include biophysical and chemical disturbance to sediments, microbes, microfauna, and microflora, epiphytes, and the impairment and mortality of secondary producers residing in the seagrass canopy and sediments (e.g. invertebrates, crustaceans, fishes, waterfowl) (Diaz-Piferrer 1962, Tatem et al. 1978, den Hartog \& Jacobs 1980, Carls \& Meador 2009). Response actions and cleanup efforts in seagrass beds and adjacent shorelines can also cause environmental degradation and seagrass loss (Zieman et al. 1984, NOAA 2011). In several field assessments following oil spills, the most severe impacts to seagrasses were documented in shallow subtidal and intertidal habitats where petroleum and weathered byproducts came into prolonged direct contact with seagrasses, fauna, other flora, and sediments. Generally, there is agreement that deeper subtidal meadows are less vulnerable to exposure (Zie- man et al. 1984, Durako et al. 1993), and the potential impacts of oil depend on the unique bio-physical characteristics of a site, such as distance from the source, weathering, tidal range, water depth, wind and wave exposure, currents, substrate type, and species composition (Zieman et al. 1984, Kenworthy et al. 1993, Hayes et al. 1993).

Given the wide range of potential impacts of oiling on seagrasses and the documentation of Deepwater Horizon oiling in shallow waters and shorelines of the Chandeleurs, the objectives of this study were (1) to determine the degree and extent of Deepwater Horizon oil exposure in seagrass meadows at the Chandeleur Islands, (2) characterize the communities of seagrasses exposed, and (3) quantitatively assess the distribution and abundance of seagrasses following the exposure.

\section{MATERIALS AND METHODS}

\section{Study site}

The Chandeleurs are a north-south oriented chain of narrow, arcuate, transgressive barrier islands slightly elevated above sea level and located $\sim 50 \mathrm{~km}$ south of Gulfport, Mississippi, and $125 \mathrm{~km}$ north of the Deepwater Horizon oil well (Fig. 1). Seagrass meadows occur on a shallow shelf extending 1 to $2 \mathrm{~km}$ westward of the islands to a slightly elevated subtidal back barrier bar where the shelf terminates in the relatively deeper water of Chandeleur Sound (Poirrier \& Handley 2007, Pham et al. 2014). The islands deflect wind, wave, and current energy from the open GoM, making the western fringing shelf a semi-protected lagoon-like environment with shallow water $(\leq 2.0 \mathrm{~m})$ well within the photic zone and physically ideal for seagrasses to thrive.

\section{General sampling design and chronology}

Initial exposure sampling (June 2010)

Sediment and plant samples were collected opportunistically in conjunction with an ongoing project designed to sample 12 locations with seagrasses in the Chandeleur Islands (Fodrie \& Heck 2011; Fig. 2). 
Despite initial efforts to conduct pre-spill sampling of ambient conditions, we were unable to acquire samples at the Chandeleur Islands until 2 June 2010; therefore, pre-exposure ambient concentrations of oil-related compounds at the Chandeleur Islands could not be confirmed.

Post-spill exposure sampling

(August-September 2010)

Initially, the SCAT data were used to qualitatively establish a preliminary stratification of the Chandeleur Islands into (1) heavy oiling (southern region), (2) moderate oiling (central region), and (3) no oiling (northern region) and were incorporated into field sampling plans between 31 August and 2 September 2010 (Fig. 2). The sampling plan relied on the best available knowledge of seagrass presence/absence based on prior mapping studies (Handley et al. 2007) and knowledge of the proximity of known seagrass beds to oiled shorelines determined by SCAT surveys. For initial selection of sampling stations, postHurricane Katrina seagrass survey data from the coast of Mississippi and Alabama (Byron \& Heck 2006) were used to help determine sampling density for small, discontinuous submerged aquatic vegetation (SAV) beds in the northern GoM. Statistical analysis of these data determined that a distance of $400 \mathrm{~m}$ between sample stations was required to meet the following decision parameters: Type I error or $\alpha$ (erroneously declaring a site non-impacted) $=5 \%$ ( significance or confidence $=95 \%$ ); Type II error or $\beta$ (erroneously declaring a site impacted) $=10 \%$, or a test power of $90 \%$ to correctly reject the null hypothesis; and test resolution or $\Delta$, which is the percent change in mean value detected at $95 \%$ confidence. Additionally, a target distance of approximately 500 $\mathrm{m}$ between stations was determined sufficient to detect the desired percent change in observed SAV conditions at a site relative to those observed at a comparable reference site with $95 \%$ confidence (Type I error $=5 \%$ ) and $90 \%$ statistical test power (Type II error $=10 \%$ ).

Post-spill exposure sampling (June 2011)

Based on further inspection of SCAT data, surface oiling in NAIP aerial imagery, and laboratory screening of the initial exposure samples obtained in 2010, the preliminary stratification of oiling categories were modified in June 2011 to include only the cen- tral and southern regions of the Chandeleurs with the addition of more sampling stations to gain wider spatial coverage across the shelf (Fig. 2b,c). Several stations from 2010 were also resampled to determine persistence of exposure over time.

\section{Oil exposure sampling methods and analyses}

\section{Sediment samples}

Samples were collected in the top $2 \mathrm{~cm}$ of the sediment and subjected to laboratory analysis for total polycyclic aromatic hydrocarbon (tPAH) surrogatecorrected concentrations, calculated based on the summation of $54 \mathrm{PAH}$ analytes including parent PAHs and selected alkylated homologs listed in Forth et al. (2015) (see Supplement 2 at www.int-res.com/ articles/suppl/m576p145_supp.pdf for a list of PAHs). If the concentration of a given compound in a sample was not detected, it was treated as a 0 value in the summation. Two other PAH sums were also used to help distinguish types of PAHs: (1) PAHs associated with petroleum, like oil from the DWH spill (petrogenic) and (2) PAHs associated with the partial combustion or pyrolysis of organic matter (pyrogenic) (Emsbo-Mattingly \& Martin 2015).

PAHs, including alkyl homologues, were analyzed in compliance with modified US Environmental Protection Agency method 8270 (US EPA 2015), utilizing gas chromatography with low-resolution mass spectrometry in the selected ion monitoring mode. The analytical chemistry results were subjected to rigorous quality assurance/quality control and validation procedures, as described in the NRDA Analytical Quality Assurance Plan (NOAA 2014) and Data Validation Plan (EcoChem 2011), respectively.

\section{Seagrass tissue}

Plant tissue samples identified as leaves and stems were obtained from the seagrass meadow canopy and sub-sampled twice in the laboratory. One subsample, referred to as 'external materials,' included only epiphytes and inorganic material loosely adhered to the leaves. This material was gently washed from the leaves and rinsed with dichloromethane, and the resulting rinsate was dried and measured for PAHs. The other sub-sample was rinsed with deionized water and homogenized before analysis. PAHs were analyzed as described above for the sediment samples. 


\section{Confirmation of oiling using SAR data}

SAR identifies very thin surface oil slicks by detecting a change in backscatter resulting from oil-dampening surface capillary waves (Graettinger et al. 2015). SAR data were collected, compiled, and analyzed from 25 April to 26 July 2010, and an estimate of cumulative oiling per $50 \mathrm{~m} \times 50 \mathrm{~m}$ grid area was calculated by adding overlapping grid cells to determine total oiled days. In order to calculate the average oil on water days for a particular site, seagrass polygonal areas delineated using fall 2010 aerial imagery (see Fig. 5) were spatially joined to the cumulative oiling raster grid dataset in ArcGIS software (Fig. 4). Each seagrass area less than $2500 \mathrm{~m}^{2}$ was associated with the closest $2500 \mathrm{~m}^{2}$ grid estimate, while larger seagrass areas were assigned the average oil on water days for encompassed grid cells. Finally, a spatially-weighted average number of oil on water days was calculated for the Chandeleur Islands.

\section{Characterization of Chandeleur Island seagrasses}

Post-exposure sampling (August/September 2010)

Initially, the selection of sample sites was guided by the criteria described above. Seagrass characteri- zation and exposure sampling were conducted at the same stations: (1) no oiling in the northern region $(\mathrm{n}=4)$, (2) moderate oiling in the central region $(\mathrm{n}=9)$, and (3) heavy oiling in the southern region $(\mathrm{n}=8)$, for a total of 21 stations (Fig. 2).

Field assessments of the cover, abundance, and general condition of seagrass beds in the Chandeleur Islands were conducted between 21 August and 2 September 2010, almost 4 mo after initial oiling. Field teams navigated to pre-determined geographic coordinates and verified the presence or absence of seagrass. If seagrass was absent, snorkelers conducted systematic circle searches until seagrass was located, at which time the alternate waypoint was stored in the GPS as the final sampling location.

The species composition and percent cover of seagrass at each station was estimated using a modified Braun-Blanquet visual assessment technique averaged from $0.25 \mathrm{~m}^{2}$ PVC quadrats $(\mathrm{n}=3)$ haphazardly tossed into the seagrass bed (Braun-Blanquet 1932, Kenworthy et. al. 1993, Fourqurean et al. 2001). Additionally, 3 plant/sediment cores $(15 \mathrm{~cm}$ diameter) were collected to estimate shoot density of individual species. During all sampling, observers noted if oil was present on the seagrass or sediments and made qualitative observations of oiling and the health and condition of leaves, whole shoots, rhizomes, roots, apical meristems, new shoot and rhizome growth, and epiphytes.

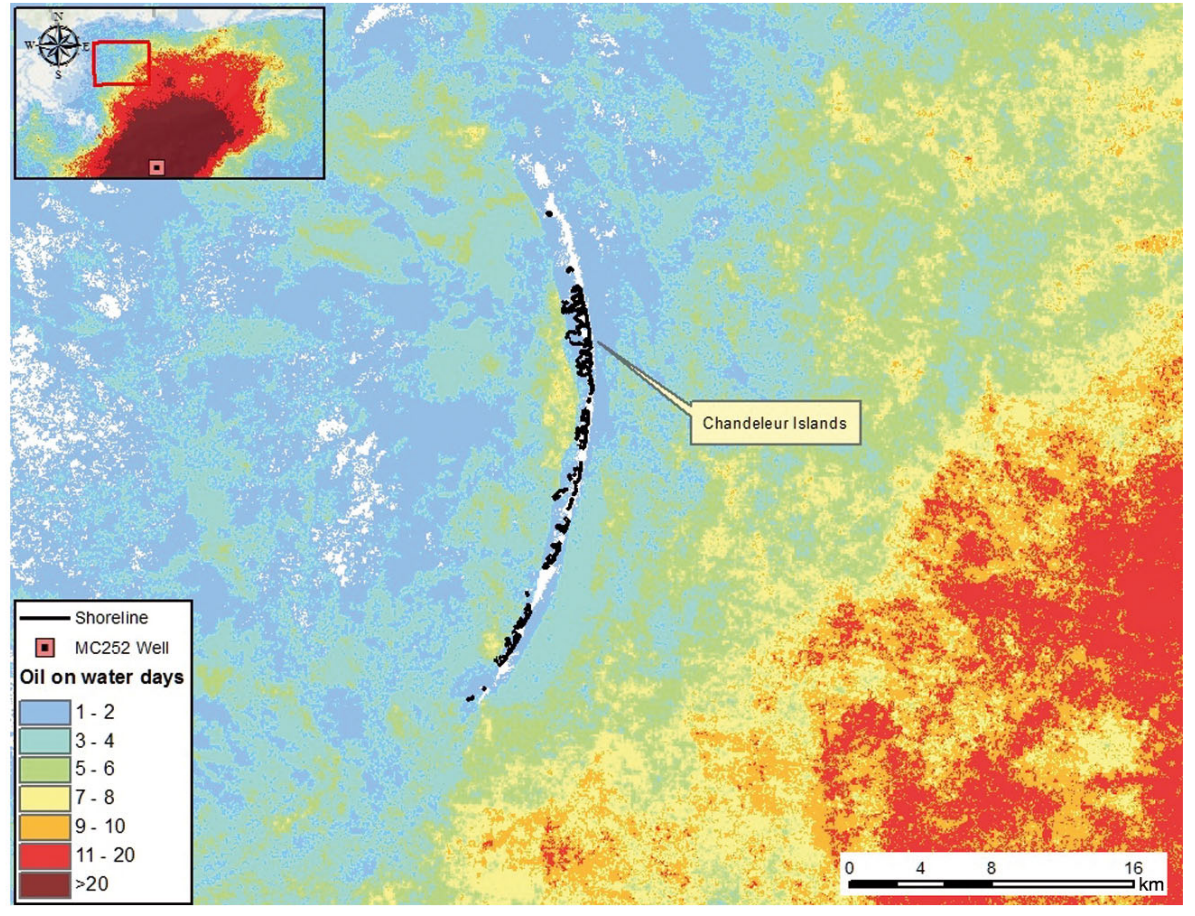

Fig. 4. Estimated number of days that oil from the Deepwater Horizon spill remained on the water surface at the Chandeleur Islands (based on Synthetic Aperture Radar satellite imagery) 
Post-exposure sampling (June 2011)

Field assessments and sample processing (20 to 22 June 2011) followed the same general protocols as in September 2010 with 3 exceptions: (1) the original oiling stratification categories were modified to focus only on the central region (formerly referred to as moderately oiled; $\mathrm{n}=10$ ) and southern region (formerly referred to as heavily oiled; $\mathrm{n}=14$; Fig. $2 \mathrm{~b}, \mathrm{c}$ ); (2) sampling intensity was increased to 5 quadrats and 5 cores within each stratum; and (3) inshore, mid-shore, and offshore stations were sampled to gain more comprehensive shelf-wide information about the seagrass beds.

\section{Aerial imagery interpretation, seagrass mapping, and change analysis}

A hybrid imagery analysis technique incorporating automated object-based imagery analysis (OBIA) (Benz et al. 2004) and traditional photo-interpretation methods (Handley et al. 2007) was used to map the presence/absence of seagrasses in high-resolution aerial imagery acquired on 3 dates in the fall of 2010, 2011, and 2012 (Fig. 5) (Handley et al. 2010, NOAA 2013). Specific additional details on the hybrid method are provided in Supplement 3 at www. int-res.com/articles/suppl/m576p145_supp.pdf. Fall imagery was the first available opportunity and coinci-
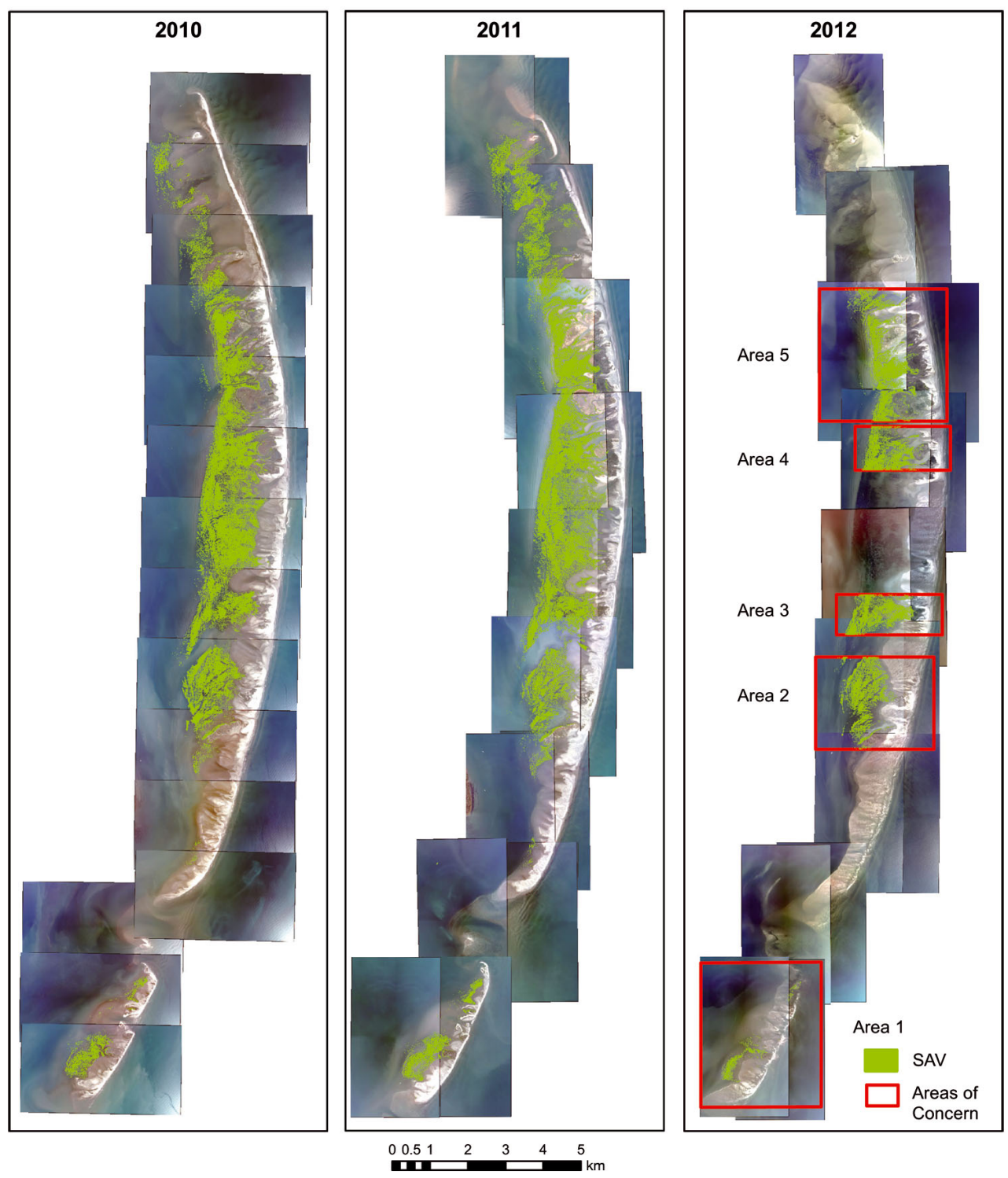

Fig. 5. High-resolution aerial photograph and interpreted classification of seagrass (submerged aquatic vegetation, SAV) presence (green areas) for 3 years (October 2010, 2011 and 2012). Also shown highlighted in the red polygons are the 5 areas of concern where detailed change analyses were conducted 
dently the preferred signature index period, since the meadows were expected to be at their maximum extent and biomass. There was no reliable source of prespill imagery, so October 2010 imagery was considered baseline for the analysis. The 12-bit imagery, with a pixel resolution of $0.3 \mathrm{~m}$, was collected using multiple DMS sensors and met ASPRS Class 2, 1:24000 scale accuracy standards, which limit the RMS error in $x$ or $y$ to $1.2 \mathrm{~m}$. Complementary ground truth information on seagrass distribution, abundance, and species composition were obtained during field sampling at the Chandeleur Islands on 2 June 2010 (Fodrie \& Heck 2011), between 31 August and 2 September 2010, and again between 20 and 22 June 2011.

The mapping and change analysis classification scheme was binary (presence/absence of seagrass), consisting of 2 classes: seagrass (SAV) and not seagrass (NOT SAV). Although the classification scheme was binary, samples of many other features were identified in order to be removed from consideration as seagrass, and these consisted primarily of sand substrates and other non-seagrass features (e.g. detritus). The change detection analysis consisted of 2 parts: (1) change between 2010 and 2011 along the full length of the Chandeleur Islands, and (2) change between all 3 dates of mapping (2010, 2011, and 2012) within 5 areas of concern (AOCs) identified within the Chandeleur Islands based on plumes of surface oil observed in NAIP imagery (10 May 2010; Fig. 3) in combination with SCAT information (Fig. 2) and field data indicating exposure to MC252 oil (see 'Results').

Since the objective of the change detection was to identify areas of seagrass loss corresponding with documented oil exposure, we refined the analysis to discriminate between natural losses and those potentially related to oil exposure. 'Core areas' were identified and delineated within each of the AOCs (see Supplements $3 \& 4$ at www.int-res.com/articles/ suppl/m576p145_supp.pdf). Core areas represent areas where imagery interpretation could not be attributed to seagrass losses due to natural processes between 2010 and 2012.

\section{RESULTS}

\section{tPAH exposure}

\author{
Sediments
}

The highest tPAH concentrations, $312 \pm 184 \mathrm{ppb}$ (mean $\pm \mathrm{SE}$ ), were recorded during sampling between 31 August and 2 September 2010 when values were nearly 8 times higher than initially observed on 2 June 2010 (40.8 $\pm 9.1 \mathrm{ppb}$; Table 1). Likewise, the maximum recorded value in the August/September samples was also demonstrably higher (3998 ppb) than the maximum in June (105 ppb). Concentrations of petrogenic PAHs followed the same temporal pattern, with higher values in August/September (285 \pm 171; $\max =3713 \mathrm{ppb})$ than first recorded in June $(27.0 \pm 6.1 \mathrm{ppb} ; \mathrm{Max}=75.4 \mathrm{ppb})$ (Table 1). In June 2011, approximately 1 yr after initial oiling occurred, sediment tPAHs $(69.7 \pm 9.9 \mathrm{ppb})$ and petrogenic PAHs $(50.7 \pm 9.1 \mathrm{ppb})$ had both declined, but were still higher than values recorded initially in June 2010 (Table 1).

\section{Plant tissue}

As was the case for sediments, concentrations of tPAHs were higher in August/September 2010 $(44.2 \pm 12.4 \mathrm{ppb})$ than in June $2010(3.5 \pm 0.5 \mathrm{ppb})$ (Table 2). Likewise, maximum tPAHs (264 ppb) in August/September 2010 were 35 times higher than in June (7.4 ppb). The petrogenic PAH mean (38.0 \pm $11.1 \mathrm{ppb}$ ) was also higher in August/September than recorded in June $(1.4 \pm 0.3 \mathrm{ppb})$ and declined $1 \mathrm{yr}$ later, in June $2011(8.2 \pm 4.5 \mathrm{ppb})$.

\section{External materials}

High concentrations of tPAHs were recorded in the external materials rinsed from the seagrass leaves

Table 1. Summary of mean $( \pm$ SE) total polycyclic aromatic hydrocarbons (tPAH) and petrogenic (PET) and pyrogenic (PYR) $\mathrm{PAH}$ concentrations in sediments at the Chandeleur Islands, Louisiana, on 3 sampling dates (given as $\mathrm{mm} / \mathrm{dd} / \mathrm{yyyy}$ ). Also shown are the maximum (max) values for each and the number of samples $(\mathrm{N})$. All results are in parts per billion (ppb)

\begin{tabular}{|lccccccc|}
\hline Sampling date & N & Mean tPAH & tPAH max & Mean PET PAH & PET PAH max & Mean PYR PAH & PYR PET max \\
\hline $06 / 02 / 2010$ & 12 & $40.8 \pm 9.1$ & 105 & $27.0 \pm 6.1$ & 75.4 & $13.6 \pm 3.1$ & 30.0 \\
$08 / 31-09 / 02 / 2010$ & 22 & $312 \pm 184$ & 3998 & $285 \pm 171$ & 3713 & $26.3 \pm 12.8$ & 283 \\
$06 / 20-06 / 22 / 2011$ & 52 & $69.7 \pm 9.9$ & 425 & $50.7 \pm 9.1$ & 395 & $19.0 \pm 2.1$ & 91.9 \\
\hline
\end{tabular}


Table 2. Summary of mean $( \pm \mathrm{SE})$ total polycyclic aromatic hydrocarbons (tPAH), petrogenic (PET), and pyrogenic (PYR) PAH concentrations in 2 sample types: plant tissue (Plant) and external material rinsed from plant tissue (EM) at the Chandeleur Islands, Louisiana, on 3 sampling dates (given as mm/dd/yyyy). Also shown are the maximum (max) values for each and the number of samples $(\mathrm{N})$. All results are in parts per billion (ppb)

\begin{tabular}{|lcccccccc|}
\hline Type & Sampling date & $\mathrm{N}$ & Mean $\mathrm{TPAH}$ & tPAH max & Mean PET PAH & PET PAH max & Mean PYR PAH PYR PET max \\
EM & $06 / 02 / 2010$ & 12 & $67239 \pm 42789$ & 535598 & $28710 \pm 16590$ & 208300 & $38524 \pm 26339$ & 327298 \\
Plant & $06 / 02 / 2010$ & 12 & $3.5 \pm 0.5$ & 7.40 & $1.4 \pm 0.3$ & 2.91 & $1.9 \pm 0.3$ & 4.09 \\
EM & $08 / 31-09 / 022010$ & 21 & $174217 \pm 75929$ & 1661945 & $139890 \pm 70934$ & 1541760 & $34224 \pm 8460$ & 148970 \\
Plant & $08 / 31-09 / 022010$ & 21 & $44.2 \pm 12.4$ & 264 & $38.0 \pm 11.1$ & 234.2 & $6.2 \pm 1.4$ & 29.9 \\
EM & $06 / 20-06 / 222011$ & 24 & $47417 \pm 22827$ & 569786 & $38532 \pm 22277$ & 526910 & $10974 \pm 2225$ & 42876 \\
Plant & $06 / 20-06 / 222011$ & 26 & $10.0 \pm 5.0$ & 132 & $8.2 \pm 4.5$ & 120 & $1.9 \pm 0.5$ & 12.1 \\
\hline
\end{tabular}

(Table 2). As was the case for both plant tissue and sediments, the highest concentrations were recorded in the August/September sampling (174 $217 \pm$ $75929 \mathrm{ppb}$ ) and were 2.6 times greater than in June 2010 (67 $239 \pm 42789 \mathrm{ppb})$. By June 2011, the tPAH concentration had declined (47 $417 \pm 22827 \mathrm{ppb})$ and was less than the value recorded $1 \mathrm{yr}$ earlier. Maximum tPAH values followed the same temporal pattern as did petrogenic PAHs, which were nearly 5 times higher in August/September 2010 (139890 \pm $70934 \mathrm{ppb})$ than in June $2010(28710 \pm 16590 \mathrm{ppb})$ and declined to $8.2 \pm 4.5 \mathrm{ppb}$ in June 2011 .

\section{Seagrass distribution, species composition, and abundance}

\section{August/September 2010}

In late August 2010, approximately 3 mo after Deepwater Horizon oil first arrived at the Chandeleur Islands, the spatial distribution of seagrasses on the shallow shelf west of the islands was discontinuous (Fig. 5). The subtidal and intertidal landscape consisted of a mosaic of seagrass patches distributed in varying sizes among areas of unvegetated and sparsely vegetated bottom. Generally, meadows in the vicinity of the central region of the islands were larger and relatively more continuous than the meadows in the northern and southern regions, which were more fragmented.

Five of the 6 species of seagrass known to occur in the northern GoM were observed, but only 3 were actually sampled in the cores and quadrats (Table 3 ). Halodule wrightii was the most commonly encountered species, followed by $R$. maritima. Thalassia testudinum was observed at just 2 stations in the central region. Syringodium filiforme and Halophila engelmannii were observed in the sampling vicinity, but did not occur in any of the quadrats or cores.

Of the 21 stations sampled, 17 were monospecific and 4 were mixed seagrass species stations with the co-occurrence of $H$. wrightii and $R$. maritima. Mixed species stations were observed in both the central and southern regions. Average seagrass cover (all species combined) was $58 \pm 21$ (SE) \% in the southern region, $81 \pm 14 \%$ in the central region, and $78 \pm 9 \%$ in the northern region. $H$. wrightii densities ranged from 2000 shoots $\mathrm{m}^{-2}$ in the southern region to 9100 shoots $\mathrm{m}^{-2}$ in the central region. $R$. maritima densities ranged from 1670 shoots $\mathrm{m}^{-2}$ in the southern region to 3000 shoots $\mathrm{m}^{-2}$ in the central region. No $R$. maritima was observed in the northern region. T. testudinum densities were 738 and 909 shoots $\mathrm{m}^{-2}$ at 2 stations in the central region.

Table 3. Post exposure (August/September 2010) characterization of the seagrass species community composition, water depth, and number of stations sampled with each species in the Chandeleur Islands, Louisiana. The stations were stratified into 3 preliminary oil exposure categories based on shoreline oiling data (assessed by the Shoreline Cleanup Assessment Technique): heavily oiled (southern region), moderately oiled (central region), and no oil (northern region). $\mathrm{N}=$ number of stations. Values below each species indicate the number of cores in which the species was present

\begin{tabular}{|lcccccc|}
\hline $\begin{array}{l}\text { Sampling } \\
\text { location }\end{array}$ & $\mathrm{N}$ & $\begin{array}{c}\text { Mean } \\
\text { depth (m) }\end{array}$ & $\begin{array}{c}\text { Thalassia } \\
\text { testudinum }\end{array}$ & $\begin{array}{c}\text { Halodule } \\
\text { wrightii }\end{array}$ & $\begin{array}{c}\text { Syringodium } \\
\text { filiforme }\end{array}$ & $\begin{array}{c}\text { Ruppia } \\
\text { maritima }\end{array}$ \\
\hline Southern & 8 & 0.47 & 0 & 7 & 0 & 3 \\
Central & 9 & 0.42 & 2 & 6 & 0 & 3 \\
Northern & 4 & 1.1 & 0 & 4 & 0 & 0 \\
\hline
\end{tabular}


June 2011

In June 2011, we limited our sampling sites to the central and southern regions of the islands, but obtained a wider spatial scope of samples that included inshore, mid-shelf, and outer shelf stations (Fig. 2b,c). As was the case in our first survey, the spatial distribution of seagrasses on the shelf was a mosaic of patches distributed in varying sizes among areas of unvegetated bottom. Four seagrass species were observed and quantitatively documented. The majority $(61 \%)$ of the cores had just 1 species present, but multispecies meadows were also common (Fig. 6a). At least a third of the stations were comprised of 2-species meadows, consisting of different combinations of $H$. wrightii, $R$. maritima, T. testudinum, and $S$. filiforme. Overall, $R$. maritima was the most frequently encountered species, followed in order by $H$. wrightii, T. testudinum, and S. filiforme (Fig. 6b).
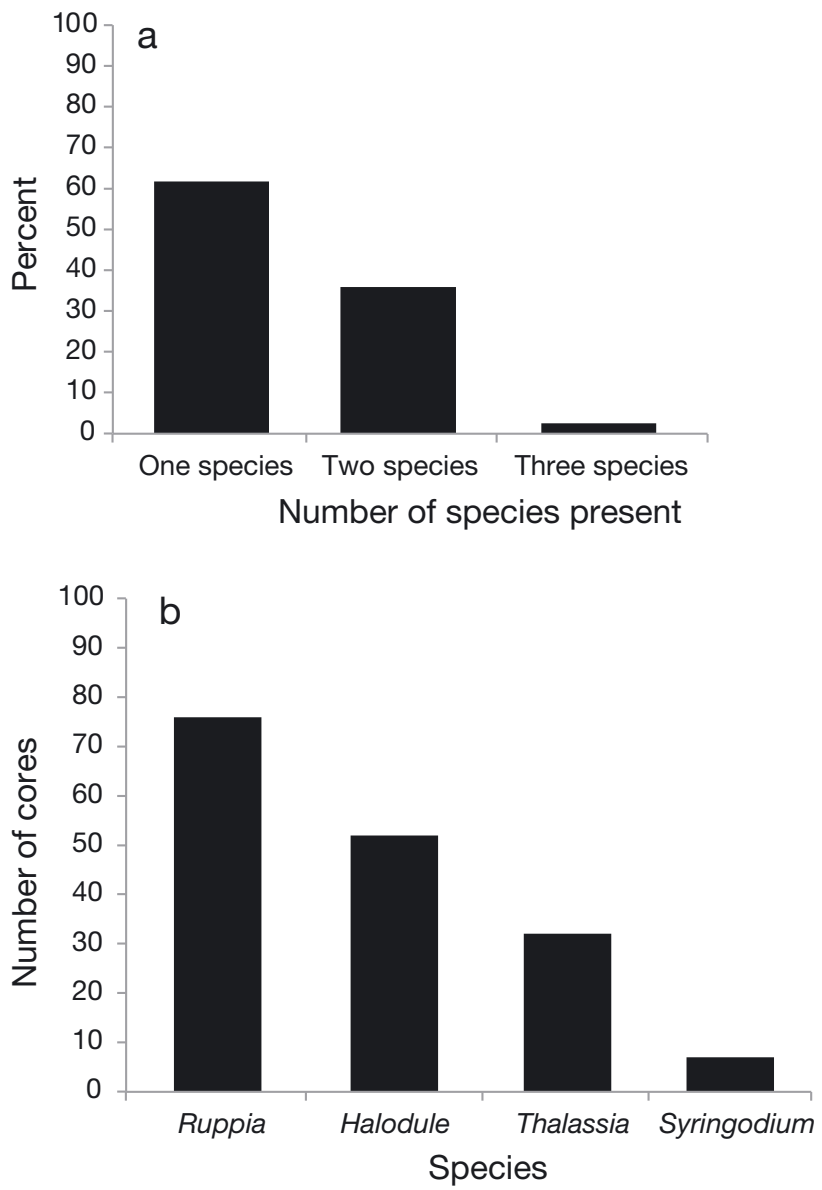

Fig. 6. (a) Percent of total cores having 1, 2, or 3 seagrass species present and (b) number of cores having each individual sea-grass species in the central and southern regions of the Chandeleur Islands in June 2011
There was some variability in the overall species abundance between the 2 regions. In the southern region, $H$. wrightii and $R$. maritima each occurred at 11 of the 14 stations sampled. $H$. wrightii was more frequently observed in the cores than any of the other 3 species (Fig. 7a). R. maritima was the next most frequently encountered species. $T$. testudinum was found at 5 of the 14 stations and was the next most frequently encountered species. $S$. filiforme was the least abundant species and was observed at only 1 station. Where seagrasses occurred, total seagrass cover in the southern region ranged from 72 to $100 \%$, averaging $92.2 \pm 5 \%$ and was heavily influenced by a higher abundance of $R$. maritima compared to sampling in August/September 2010.

In the central region of the islands, $R$. maritima was observed at 9 of the 10 stations and was the most frequently encountered species (Fig. 7b). T. testudinum was the next most frequently encountered species and was present at 5 of the 10 stations, while $H$. wrightii was less abundant than $T$. testudinum and present at 3 of the 10 stations. As in the southern
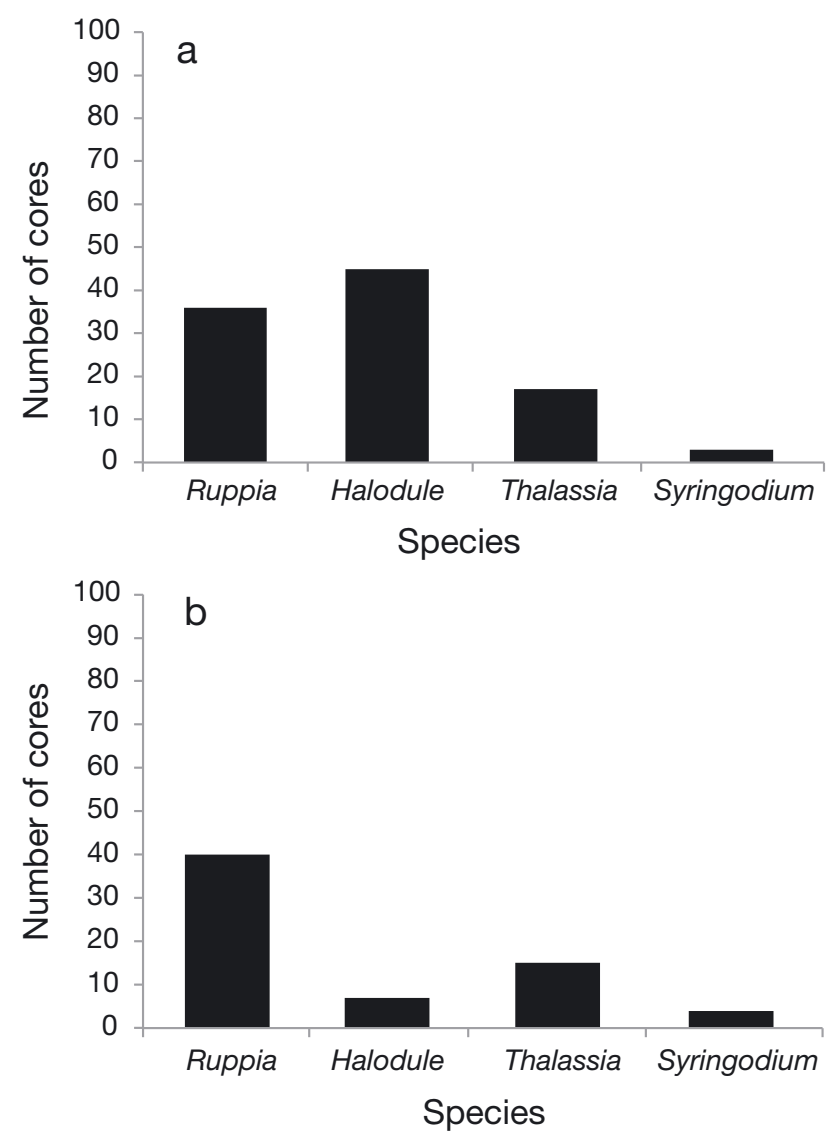

Fig. 7. Frequency of sample cores in which each species occurred in the (a) southern and (b) central regions of the Chandeleur Islands in June 2011 
region, $S$. filiforme was the least abundant species. Total seagrass cover in the central region ranged from 45 to $100 \%$, averaging $90.2 \pm 7.5 \%$.

$R$. maritima densities were lower in the southern region $\left(1195 \pm 308\right.$ shoots $\left.\mathrm{m}^{-2}\right)$ than in the central region (2654 \pm 385 shoots $\mathrm{m}^{-2}$; Fig. 8a). Additional density data obtained in this region in June 2011 (1613 \pm 509 shoots $\mathrm{m}^{-2}$; K. Heck unpubl. data) were slightly lower than our samples. Average pre-exposure densities in the central region for $R$. maritima $\left(2872 \pm 2159\right.$ shoots $\left.\mathrm{m}^{-2}\right)$, obtained between 2006 and 2010 (Fodrie \& Heck 2011), were comparable to our June 2011 densities, but had a large standard error, suggesting considerable spatial and/or inter-annual variation.
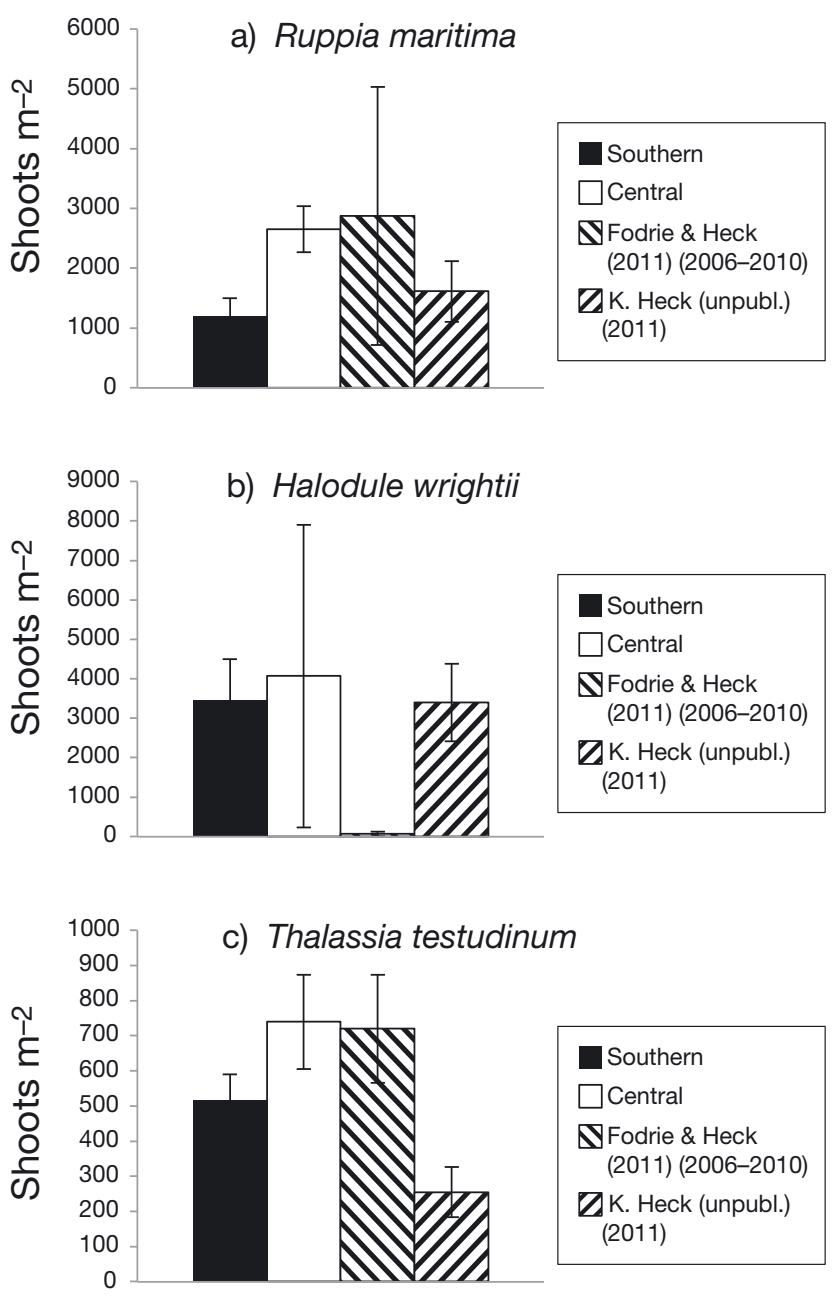

Fig. 8. Shoot density (shoots $\mathrm{m}^{-2}$ ) the in the southern and central regions of the Chandeleur Islands in June 2011 for (a) Ruppia maritima, (b) Halodule wrightii, and (c) Thalassia testudinum. Also shown are average shoot densities for the central region between 2006 and 2010 (Fodrie \& Heck 2011) and 2011 (K. Heck unpubl. data). Error bars indicate SE
$H$. wrightii densities ranged from $3451 \pm 1044$ shoots $\mathrm{m}^{-2}$ in the southern region to $4067 \pm 3840$ shoots $\mathrm{m}^{-2}$ in the central region (Fig. 8b). Additional density data $\left(3400 \pm 988\right.$ shoots $\left.\mathrm{m}^{-2}\right)$, obtained in the central region in June 2011 (K. Heck unpubl. data), were comparable to our densities. Average preexposure $H$. wrightii densities $\left(68 \pm 59\right.$ shoots $\left.\mathrm{m}^{-2}\right)$ in the central region between 2006 and 2010 (Fodrie \& Heck 2011) were much lower than our June 2011 samples (Fig. 8).

T. testudinum densities ranged from $518 \pm 72$ shoots $\mathrm{m}^{-2}$ in the southern region to $739 \pm 134$ shoots $\mathrm{m}^{-2}$ in the central region (Fig. 8c). Additional density data $\left(255 \pm 154\right.$ shoots $\left.\mathrm{m}^{-2}\right)$, obtained in the central region in June 2011 (K. Heck unpubl. data), were lower than our densities in June 2011. Average pre-exposure densities in the central region for $T$. testudinum $\left(720 \pm 154\right.$ shoots $\left.\mathrm{m}^{-2}\right)$ obtained between 2006 and 2010 (Fodrie \& Heck 2011) were comparable to our June 2011 samples.

S. filiforme was present at only 2 stations, with 1775 shoots $\mathrm{m}^{-2}$ in the central region and 1003 shoots $\mathrm{m}^{-2}$ in the southern region. These densities were higher than average pre-exposure samples taken between 2006 and 2010 (358 \pm 323 shoots $\mathrm{m}^{-2}$; Fodrie \& Heck 2011) and samples obtained in the moderate strata in June 2011 (738 \pm 237 shoots $\mathrm{m}^{-2}$; K. Heck unpubl. data).

\section{Seagrass change detection}

The first phase of the change detection along the full length of the island between fall 2010 and 2011 detected 483 acres (195.46 ha) of SAV loss and 711 acres (287.73 ha) gained, for a net positive change of 228 acres (92.27 ha). The second phase identified changes between 2010, 2011, and 2012 in the 5 AOCs (Table 4; also see Supplement 2).

Core areas were delineated to omit areas of natural processes that might be responsible for losses. For ex-

Table 4. Summary of changes in seagrass acreage in the 5 core areas in each change class category

\begin{tabular}{|lccccc|}
\hline Core area & No change & Gain & Loss & Net loss & Net gain \\
\hline 1 & 46.35 & 11.0 & 54.9 & 43.9 & 0 \\
2 & 208.26 & 35.87 & 64.44 & 28.57 & 0 \\
3 & 178.28 & 38.98 & 36.61 & 0 & 2.37 \\
4 & 178.33 & 20.99 & 47.54 & 26.55 & 0 \\
5 & 316.28 & 60.13 & 67.7 & 7.57 & 0 \\
Total & & 166.97 & 271.19 & 106.59 & 2.37 \\
\hline
\end{tabular}


ample, the core area within AOC 1 eliminates the overwash fans that were visible in the underlying 2012 post-Hurricane Isaac imagery. These fans resulted when waters washed over the island during the hurricane, depositing fans of sediment on the western side of the island and burying existing seagrass. The northern half of AOC 1 was also excluded, because this part of the island offered little physical protection to erosion and overwash burial, and the seagrass beds in this area had been experiencing serious losses prior to 2010. Subsequently, all 5 AOCs were analyzed to omit areas of natural loss (Supplement 2).

Despite evidence of oil exposure and both persistent and delayed losses, all of the core areas had some seagrass coverage that displayed no change or gains (see Supplement 4). Four of the 5 core areas displayed a net loss, while only 1 (core area 3 ) displayed a small net gain (2.37 acres, $0.959 \mathrm{ha}$ ). A total of 111.7 acres (45.20 ha) were identified as persistent loss and 159.5 acres (64.55 ha) were classified as delayed loss (see Supplement 4). Therefore the total loss (persistent + delayed loss) for all 5 core areas was estimated to be 271.19 acres (109.75 ha; Supplement 4). Accounting for the gains (2.37 acres, $0.959 \mathrm{ha})$, overall there was a net loss of 104.22 acres (42.18 ha) in the 5 core areas.

\section{DISCUSSION}

\section{Deepwater Horizon oil exposure}

The spatial and temporal signature of surface oil in aerial photography and SAR data clearly indicated that the spill threatened seagrass meadows located at the Chandeleur Islands, LA. Forensic analyses confirmed that some of the Deepwater Horizon oil was transported in surface waters shoreward into shallow coastal regions throughout the northern GoM, where it was dispersed as floating oil slicks, sheens, emulsions, submerged mats, tar balls, or dissolved in water in the Chandeleur Islands (Stout et al. 2016). Five lines of evidence presented in this study, viz. (1) shoreline oiling (SCAT data), (2) sediment and plant PAH data on 2 sampling dates, (3) concurrent forensic confirmation of Deepwater Horizon oil exposure (Stout et al. 2016), (4) visual inspection of oil on water in aerial photography, and (5) estimated oil on water days based on satellite imagery (SAR data), confirmed the exposure of seagrass meadows in the Chandeleurs to Deepwater Horizon oil.

The shoreline SCAT data confirmed what was evident from aerial photography; oil had to pass over and through the shallow shelf and seagrass meadows west of the islands to reach the shoreline. Sediments and plant tissues showed increasing concentrations of tPAHs and petrogenic PAHs forensically matched with Deepwater Horizon oil between early June and September 2010 corresponding with repeated oiling events that took place over the $87 \mathrm{~d}$ between April and July before the Deepwater Horizon well was capped. By June 2011, approximately 1 yr after exposure commenced, forensic analysis continued to detect Deepwater Horizon oil, but tPAH and petrogenic PAH concentrations had declined markedly to values only slightly higher than initially recorded in June 2010, indicating that persistent exposure was mitigated by further redistribution, weathering, biogeochemical processing, and degradation of the oil.

\section{Exposure scenario and seagrass response}

The potential susceptibility of the Chandeleur Islands' seagrasses to Deepwater Horizon oil exposure is attributed to several factors. These seagrass meadows were only $125 \mathrm{~km}$ from the Deepwater Horizon source, and because of their north-south orientation, the islands provided minimal physical protection from the oil, which had a direct pathway into the seagrass meadows on the shallow back barrier shelf (Supplement 5 at www.int-res.com/articles/suppl/ m576p145_supp.pdf). As oil was transported onto the shelf and ashore from the south and west, the islands acted as a barrier preventing the easterly transport of oil off the shelf. With a relatively small amount of tidal and wind energy to physically transport it away, it is likely that oil was temporarily concentrated on the shallow shelf and contacted the seagrasses directly in soluble and insoluble forms and became adsorbed onto suspended materials (sediments, detritus) and biota (epiphytes) that may have settled to the bottom and further exposed the seagrass and sediments to potentially toxic concentrations of petro-chemicals (Supplement 1 ). The very high concentrations of Deepwater Horizon PAHs and petrogenic PAHs in the external materials loosely adhered to the leaves (epiphytes) suggest that this exposure could have affected the epiphyte community, thereby impacting a productive and important trophic component of the system.

Additionally, tar balls were commonly encountered during sampling, and oil that was stranded along the shoreline and in shallow subtidal sediments (Stout et al. 2016, Rouhani et al. 2017, this Theme Section) may have been redistributed back onto the inter- 
tidal and subtidal shelf by wave turbulence and tidal energy leading to prolonged exposure. Subtidal, shoreline, and fringing marsh sediments and particulate detritus exposed to oiling are less cohesive than unoiled material, which may have provided a mechanism for repeated oiling of the seagrass meadows long after the well was capped (Silliman et al. 2012, Martin et al. 2015). Additionally, oiled sediments are not nearly as cohesive, and if the roots and rhizomes were impaired by exposure, seagrasses may have been more easily uprooted. This may be a partial explanation of the unvegetated gaps in substrates and water depths that normally would support seagrass.

Two field assessments and 3 consecutive years of high-resolution aerial photography confirmed that the spatial coverage of seagrasses was heterogeneously distributed across the shallow shelf west of the Chandeleur Islands. The shelf seascape was a mosaic of healthy and actively growing seagrasses in varying sized patches and large continuous meadows distributed among unvegetated and sparsely vegetated gaps. Where the seagrasses occurred, the species composition, cover, and density were comparable to seagrass meadows previously described for this region of the northern GoM (Eleuterius 1987, Green \& Short 2003, Byron \& Heck 2006, Handley et al. 2007, Carter et al. 2011, Fodrie \& Heck 2011, Pham et al. 2014). In September 2010, monospecific species communities were more common than multispecies meadows, while in June 2011, multi-species meadows were more frequent with a demonstrably larger presence of $R$. maritima. Some of this variability in species composition can be attributed to differences in the time of sampling, as well as differences in the spatial extent of our 2 sampling efforts. In September 2010, sampling focused almost exclusively on nearshore sites adjacent to the islands, while in June 2011 the survey area expanded to mid-shelf and outer-shelf sites which captured more of the spatial variation in depth, species distribution, and community composition. Based on our 2 surveys, it is evident that some portions of a diverse and structurally complex seagrass community were exposed to MC252 oil for several months between May and August 2010, and some exposure persisted into 2011, while some areas avoided exposure.

In both sampling events, Ruppia maritima and Halodule wrightii were the most commonly encountered species in high densities throughout the shelf, in both the subtidal and shallow intertidal where leaf canopies reached the water surface and would have been most vulnerable to oil exposure. We also ob- served Halodule and Ruppia in nearshore environments adjacent to shorelines with visibly evident accumulations of stranded oil. Ruppia frequently cooccurred with Thalassia testudinum and was relatively more abundant in the June 2011 samples, which may be indicative of seasonal differences in phenology and growth. Ruppia is a euryhaline, relatively fast-growing, opportunistic, and ephemeral species known to flower prolifically and colonize unvegetated areas by seed, while completing its entire life cycle in 4 mo (Moffler \& Durako 1987, Dunton 1990, Byron \& Heck 2006). Ruppia is among the most fecund seagrasses in the northern GoM and relies on rapid vegetative growth, flowering, and seed production in late spring and early summer to replenish biomass and populations. A recent experimental study demonstrated that high sediment oil concentrations impaired the production of inflorescences, fruiting bodies, and root growth of $R$. maritima (Martin et al. 2015). In June 2011, Ruppia flowering plants were commonly observed and widely distributed, with canopies occupying the entire water column up to the surface. If the conditions observed in June 2011 represented the conditions in May and June 2010 when oil first reached the Chandeleurs, Ruppia would have been especially vulnerable to exposure. The 3 other species also flower and produce seeds, and $H$. wrightii and Syringodium filiforme produce seeds that can be buried in sediment seed banks longer than 12 mo before germinating (McMillan 1991, Inglis 1999, Orth et al. 2006a). Flowering and seed production are important for both meadow maintenance and spatial dispersal of seagrasses (Kendrick et al. 2012), and it is likely that sexual reproduction of these species was also affected by Deepwater Horizon oil in 2010. Given that oil exposure was detected in sediments for at least $1 \mathrm{yr}$, it is plausible to conclude that some of the plants and sediment seed banks were chronically exposed, potentially leading to population-level impacts on the seagrasses.

The Chandeleur Islands have experienced a long history of physical instability resulting from severe storms which have reduced the overall physical size and elevation of the islands (Lavoie 2009, Mitchell et al. 2011). These storm effects and changes in water quality, mainly salinity and turbidity, have corresponded with the diminished areal abundance of seagrasses in the region (Eleuterius 1987, Poirrier \& Franze 2001, Franze 2002, Poirrier \& Handley 2007, Lavoie 2009, Pham et al. 2014). Unexpectedly, our change analysis identified a shelf-wide net gain of 228 acres (92.27 ha) of seagrass coverage between 
fall 2010 and fall 2011. This gain is notable because it signals a pause in the long-standing persistent downward trend in total seagrass coverage in the Chandeleurs and suggests that predictions for the demise of this resource may need re-evaluation. These results, combined with the high density, cover, and observed biodiversity, provide reasonable assurance that there has been no widespread catastrophic loss of seagrasses associated with oil exposure in the Chandeleur Islands.

There was, however, a conspicuous widespread distribution of unvegetated and sparsely vegetated gaps in the cover of seagrasses at water depths and in sediment types known to support their growth. Gaps among healthy seagrass meadows are not uncommon (e.g. caused by bioturbation, grazing, or physical disturbance; Uhrin et al. 2011). However, some of the gaps we observed in September 2010 and again in June 2011 corresponded with areas of documented oil exposure, and the persistence or expansion of these gaps and the formation of new gaps were considered indications of seagrass response to exposure. We also suspected that the 3 mo delay in sampling after initial oiling prevented us from directly observing and documenting visible oil entrained and accumulated in the seagrass beds, the highest concentrations of oil the seagrass and sediments may have experienced, and the most acute and potentially severe toxic effects of exposure.

The cumulative lines of exposure evidence all indicated that oiling and the degree of exposure were spatially and temporarily heterogeneous. This variability in exposure limited our scope of inferences with point samples alone. We were also handicapped by the absence of quantitative baseline data for seagrasses at the time of exposure, thus eliminating a statistically robust before and after sampling design. To overcome these limitations, we completed our assessment using high-resolution aerial imagery and quantitative change analysis of seagrass areal distribution. Without reliable pre-exposure imagery, October 2010 served as the starting reference point for seagrass coverage and the possible latent effects of exposure that may have lingered in the ecosystem for up to 2 yr. Our change detection method in the AOCs, where we documented exposure, deviated from traditional approaches which interpret areal seagrass coverage to calculate an absolute change in area between 2 time intervals. Often, the factors potentially responsible for the change in coverage are assumed to be homogeneously distributed, in which case the net gain in seagrass areal coverage documented between 2010 and 2011 would suggest that oiling had no effect on total seagrass abundance in the Chandeleur Islands. However, this would disregard evidence that oil exposure was heterogeneously distributed in space over a period of several months, and also overlooks the fact that seagrasses were heterogeneously distributed in such a way that the specific locations where oil reached the shelf may or may not have directly contacted the plant canopies and sediments. This alternative approach acknowledged that there could be areas of seagrass loss due to exposure and areas of no change or gain that were minimally exposed or not exposed at all. Furthermore, documenting all 3 categories over time ( 3 yr) acknowledges the potential latent chronic effects of exposure which were not immediately evident in field sampling following the initial exposure.

Accounting for gains, the change analysis in the 5 core areas estimated a net loss of 104.22 acres (42.18 ha). To minimize uncertainty and strengthen inferences regarding exposure, areas where changes in seagrass coverage could be attributed to natural processes and problematic interpretation signatures were excluded from this analysis. Therefore, it is plausible to attribute the net losses to acute and chronic exposure of critical plant physiological processes leading to seagrass mortality, the impairment of seagrass reproduction (sexual and/or asexual) recruitment and recolonization, and the latent effects of oil exposure on sediment biogeochemical processes. Since the imagery used in this analysis was acquired in October 2010, almost 5 mo after oil first reached the Chandeleurs, this estimate did not capture seagrass changes that might have occurred during and immediately after exposure in the late spring and summer of 2010. Thus, these estimates likely represent a conservative assessment of changes due to exposure.

\section{SUMMARY}

In the summer of 2010, the biophysical conditions on the back barrier shelf at the Chandeleur Islands were favorable to oiling from the DWH spill. Multiple lines of evidence confirmed Deepwater Horizon oil exposure on shorelines, in seagrass tissue, and in sub-tidal and intertidal sediments on the shelf. Given the known mechanisms linking petroleum toxicity to both lethal and sublethal impairment of seagrass physiology and sediment metabolism, we investigated the seagrass response to Deepwater Horizon oil exposure at the Chandeleur Islands. Despite evi- 
dence of widespread oiling on the shoreline, a shelfwide change analysis conducted between October 2010 and 2011 showed a small increase in seagrass acreage. Additional change analyses were spatially constrained to a sub-set of 5 areas where we documented exposure by 3 independent methods (aerial photography, in situ tissue and sediment samples, and satellite remote sensing) and accounted for natural variation and interpretation errors. By restricting our analysis to these 5 locations, we conclude that it is plausible that seagrass losses in these 5 study areas could be attributed to MC252 oil exposure. The apparent discrepancy between shelfwide gains and losses in the 5 areas we sub-sampled may be explained by the very nature of the spill that resulted in a complicated oiling scenario with temporally and spatially heterogeneous exposure. The release of oil from the well lasted for $87 \mathrm{~d}$, and it arrived at the Chandeleurs after variable degrees of treatment and weathering, at different times, during different water level and wind conditions, and at different stages in the life histories of the seagrass species.

Having avoided a shelf-wide catastrophic loss of seagrass due to oil exposure, the Chandeleur Islands continue to support a diverse and extensive habitat of mixed-species seagrass communities providing important and economically valuable ecological services, one of which is physical stabilization of the shallow back barrier shelf that forms the submerged foundation which the westerly migrating barrier depends on to maintain its somewhat tenuous elevation above sea level. Sediments accreting on the shelf are trapped and stabilized by the seagrasses which also help preserve the physical integrity of the back barrier marsh by protecting the emergent wetland fringe from wind wave energy. Thus, seagrasses function to delay the predicted transition of the emergent islands to submerged shoals similar to what has occurred farther south in the Chandeleurs (Lavoie 2009). The notable pause in the shelf-wide decline indicates that recent predictions suggesting the impending extirpation of this unique and important seagrass system needs some reconsideration. Data on the spatial distribution, species composition, and abundance of seagrasses provided by this study can be utilized by scientists and resource managers as a quantitative contemporary baseline for (1) designing and implementing future monitoring programs, (2) developing resource management and restoration plans for the islands, and (3) contemplating future actions in response to natural disturbances and/or anthropogenic disasters in the region.
Acknowledgements. This study was conducted within the Deepwater Horizon NRDA investigation, which was cooperatively conducted by NOAA, Federal (DOI) and State Trustee (LA, MS, AL, FL) natural resource agencies, NOAA contractors, and BP. The scientific results and conclusion of this publication, as well as any views or opinions expressed herein, are those of the authors only. The authors declare no competing financial interest in the publication of this study. Funding for the study was provided by NOAA through Industrial Economics, Corp. (Cambridge, MA) as part of the NRDA process. For field and laboratory assistance, special thanks to: Newfields LLC staff; Meg Goecker, Sustainable Ecosystem LLC; Sean Meehan, NOAA; Shay Viehman, Jenny Vander Pluym, and Don Field, CCFHR, NCCOS, NOAA; and Dr. Kenneth Heck and staff, Dauphin Island Sea Lab. We also thank Ruth Spell, Jonathan Nicholas, and Colin Sutherland, as well as Tatiana Manidis from Newfields LLC for assistance with the object-based image classification, GIS expertise, figure preparation, and document editing, and Catherine Lockwood with CNL World for editing the technical report.

\section{LITERATURE CITED}

Barbier EB, Hacker SD, Kennedy C, Koch EW, Stier AC, Silliman BR (2011) The value of estuarine ecosystems. Ecol Monogr 81:169-193

Beck MW, Heck KL Jr, Able KW, Childers DL and others (2001) The identification, conservation, and management of estuarine and marine nurseries for fish and invertebrates. Bioscience 51:633-641

* Benz UC, Hofmann P, Willhauck G, Lingenfelder I, Heynen M (2004) Multi-resolution, object-oriented fuzzy analysis of remote sensing data for GIS-ready information. ISPRS J Photogramm Remote Sens 58:239-258

Braun-Blanquet J (1932) Plant sociology - the study of plant communities. Translated, revised, and edited by G.D. Fuller and H.S. Conrad. Koeltz Scientific Books, Koenigstein

Byron D, Heck KL (2006) Hurricane effects on seagrasses along Alabama's Gulf coast. Estuaries Coasts 29:939-942

Carls MG, Meador JP (2009) A perspective on the toxicity of petrogenic PAGs to developing fish embryos related to environmental chemistry. Hum Ecol Risk Assess 15: 1084-1098

Carter GA, Lucas KL, Biber PD, Criss GA, Blossom GA (2011) Historical changes in seagrass coverage on the Mississippi barrier islands, northern Gulf of Mexico, determined from vertical aerial imagery (1940-2007). Geocarto Int 26:663-673

den Hartog C, Jacobs RPWM (1980) Effects of the 'Amoco Cadiz' oil spill on and eelgrass community at Roscoff (France) with special reference to the mobile benthic fauna. Helgol Meeresunters 33:182-191

Diaz-Piferrer M (1962) The effects of an oil spill on the shore of Guanica, Puerto Rico. Association of Island Marine Laboratories, Fourth Meeting, Caraibisch Marien Biologisch Instituut, Curaçao, Netherland Antilles, p 12-13

* Duarte CM, Chiscano CL (1999) Seagrass biomass and production: a reassessment. Aquat Bot 65:159-174

Duarte CM, Middelburg JJ, Caraco N (2005) Major role of marine vegetation on the oceanic carbon cycle. Biogeosciences 2:1-8

* Dunton KH (1990) Production ecology of Ruppia maritima L. 
s.1. and Halodule wrightii Aschers, in two subtropical estuaries. J Exp Mar Biol Ecol 143:147-164

"Durako MJ, Kenworthy WJ, Fatemy SMR, Valavi H, Thayer GW (1993) Assessment of the toxicity of Kuwait crude oil on the photosynthesis and respiration of seagrasses of the Northern Gulf. Mar Pollut Bull 27:223-227

EcoChem (2011) Data validation plan, Revision 1. Mississippi Canyon 252 DWH NRDA, Seattle, WA

Eleuterius LN (1987) Seagrass ecology along the coasts of Alabama, Louisiana, and Mississippi. Fla Mar Res Publ 42:11-24

Emsbo-Mattingly S, Martin C (2015) Distribution and weathering of Macondo oil in nearshore soils, sediments, and tissues collected between spring 2010 and spring 2012 based on chemical fingerprinting methods. Appendices. DWH NRDA Chemistry Technical Working Group Report. Available at https://pub-dwhdatadiver.orr.noaa. gov/dwh-ar-documents/946/DWH-AR0260380.pdf (accessed on 26 January 2015)

Fodrie FJ, Heck KL Jr (2011) Response of coastal fishes to the Gulf of Mexico oil disaster. PLOS ONE 6:e21609

Fonseca MS, Bell SS (1998) Influence of physical setting on seagrass landscapes near Beaufort, North Carolina, USA Mar Ecol Prog Ser 171:109-121

Fonseca MS, Zieman JC, Thayer GW, Fisher JS (1983) The role of current velocity in structuring eelgrass (Zostera marina) meadows. Estuar Coast Shelf Sci 17:367-380

Forth HP, Morris JM, Cacela D (2015) Explanation of analytes included in the total polycyclic aromatic hydrocarbon sums used by the Deepwater Horizon Natural Resource Damage Assessment Toxicity Group. (TOX_ TR.11). DWH Toxicity NRDA TWG, Boulder, CO

Foster M, Charters AC, Neushul M (1971a) The Santa Barbara oil spill, Part 1: Initial quantities and distribution of pollutant crude oil. Environ Pollut 2:97-113

Foster M, Neushul M, Zingmark R (1971b) The Santa Barbara oil spill, Part 2: Initial effects on intertidal and kelp bed organisms. Environ Pollut 2:115-134

Fourqurean JW, Willsie A, Rose CD, Rutten LM (2001) Spatial and temporal pattern in seagrass community composition and productivity in south Florida. Mar Biol 138:341-354

Franze CD (2002) Barrier island seagrass and geomorphic interactions: a case study of hurricane damage and efficacy of restoration efforts at the Chandeleur Islands. MSc thesis, University of New Orleans, New Orleans, LA

Graettinger G, Holmes J, Garcia-Pineda O, Hess M and others (2015) Integrating data from multiple satellite sensors to estimate daily oiling in the northern Gulf of Mexico during the Deepwater Horizon Oil spill. Tech Rep. Available at https://pub-dwhdatadiver.orr.noaa.gov/dwh-ardocuments/946/DWH-AR0062879.pdf (accessed on 26 January 2015)

Green EP, Short FT (2003) World atlas of seagrasses. UNEPWCMC, University of California Press, Berkley, CA

Handley L, Altsman D, DeMay R (2007) Seagrass status and trends in the northern Gulf of Mexico: 1940-2002: U.S. Geological Survey Scientific Investigations Report 20065287. https://pubs.usgs.gov/sir/2006/5287/index.html

Handley LR, Cretini C, Wells C, Heleine GF and others (2010) Technical specifications and scope of work/services for aerial image acquisition and image processing in support of the MC252 NRDA process: Fall 2010 through Spring 2012. Available at https://pub-dwhdatadiver.orr.noaa.gov/dwh-ar-documents/962/DWHAR0021888.pdf (accessed on 26 January 2015)
Hatcher AI, Larkum AWD (1982) The effects of short term exposure to bass strait crude oil and corexit 8667 on benthic community metabolism in Posidonia australis Hook.f. dominated microcosms. Aquat Bot 12:219-227

* Hayes MO, Michel J, Montello TM, Aurand DV and others (1993) Distribution and weathering of shoreline oil one year after the Gulf War oil spill. Mar Pollut Bull 27: 135-142

Inglis GJ (1999) Variation in the recruitment behavior of seagrass seeds: implications for population dynamics and resource management. Pac Conserv Biol 5:251-259

* Jackson JBC, Cubit JD, Keller BD, Batista V and others (1989) Ecological effects of a major oil spill on Panamanian coastal marine communities. Science 243:37-44

Kendrick GA, Waycott M, Carruthers TJB, Cambridge ML and others (2012) The central role of dispersal in the maintenance and persistence of seagrass populations. Bioscience 62:56-65

Kenworthy WJ, Durako MJ, Fatemy SMR, Valavi H, Thayer GW (1993) Ecology of seagrasses in northeastern Saudi Arabia one year after the Gulf War oil spill. Mar Pollut Bull 27:213-222

Larkum AWD, Orth RJ, Duarte CM (eds) (2006) Seagrasses: biology, ecology and conservation. Springer, Amsterdam

Lavoie D (ed) (2009) Sand resources, regional geology, and coastal processes of the Chandeleur Islands coastal system-an evaluation of the Breton National Wildlife Refuge. U.S. Geological Survey, Scientific Investigations Report 2009-5252. https://pubs.usgs.gov/sir/2009/5252/ downloads/SIR2009-5252.pdf

* Martin CW, Hollis LO, Turner RE (2015) Effects of oilcontaminated sediments on submerged vegetation: an experimental assessment of Ruppia maritima. PLOS ONE 10:e0138797

* McMillan C (1991) The longevity of seagrass seeds. Aquat Bot 40:195-198

Michel J, Owens EH, Zengel S, Graham A and others (2013) Extent and degree of shoreline oiling: Deepwater Horizon oil spill, Gulf of Mexico, USA. PLOS ONE 8:e65087

* Michot TC, Chadwick PC (1994) Winter biomass and nutrient values of three seagrass species as potential foods for redheads (Aythya americana Eyton) in Chandeleur Sound, Louisiana. Wetlands 14:276-283

Mitchell B, Reahard R, Billiot A, Brown T, Childs L (2011) Assessment of tropical cyclone induced transgression of the Chandeleur Islands for restoration and wildlife management. In: Weber S (ed) Rethinking protected areas in a changing world. Proc GWS Biennial Conference on Parks, Protected Areas, and Cultural Sites. The George Wright Society, Hancock, MI, p 224-230

Moffler MD, Durako MJ (1987) Reproductive biology of the tropical-subtropical seagrasses of the southeastern United States. Fla Mar Res Publ 42:77-88

NOAA (National Oceanic and Atmospheric Administration) (2011) Mississippi Canyon 252/Deepwater Horizon scope of work for emergency restoration project: response impacts to seagrasses within Alabama, Florida, Louisiana and Mississippi coastal waters. Available at https://pubdwhdatadiver.orr.noaa.gov/dwh-ar-documents/918/DWHAR0014548.pdf (accessed on 26 January 2015)

NOAA (2013) Assessment plan concerning aerial imagery in the northern Gulf of Mexico (2013). Available at https:// pub-dwhdatadiver.orr.noaa.gov/dwh-ar-documents/962/ DWH-AR0200192.pdf (accessed on 26 January 2015)

NOAA (2014) Analytical quality assurance plan. Mississippi 
Canyon 252 (Deepwater Horizon) Natural Resource Damage Assessment, Version 4.0. https://pub-dwhdatadiver. orr.noaa.gov/dwh-ar-documents/945/DWH-AR0101767. pdf (accessed on 20 January 2017)

Orth RJ, Harwell MC, Inglis GJ (2006a) Ecology of seagrass seeds and dispersal strategies. In: Larkum AWD, Orth RJ, Duarte CM (eds) Seagrasses: biology, ecology and conservation. Springer, Amsterdam, p 111-133

* Orth RJ, Carruthers TJB, Dennison WC, Duarte CM and others (2006b) A global crisis for seagrass ecosystems. Bioscience 56:987-996

Peirano A, Damasso V, Montefalcone M, Morri C, Bianchi CN (2005) Effects of climate, invasive species and anthropogenic impacts on the growth of the seagrass Posidonia oceanica (L.) Delile in Liguria (NW Mediterranean Sea). Mar Pollut Bull 50:817-822

Peterson $\mathrm{CH}$, Anderson SS, Cherr GN, Ambrose RF and others (2012) A tale of two spills: novel science and policy implications of an emerging new oil spill model. Bioscience 62:461-469

Pham LT, Biber PD, Carter GA (2014) Seagrasses in the Mississippi and Chandeleur Sounds and problems associated with decadal-scale change detection. Gulf Mex Sci 32:24-43

Poirrier MA, Franze CD (2001) Seagrass restoration in the Chandeleur Islands after Hurricane Georges. University of New Orleans Department of Biological Sciences, New Orleans, LA

Poirrier MA, Handley LR (2007) Chandeleur Islands. In: Handley L, Altsman D, DeMay R (eds) Seagrass status and trends in the northern Gulf of Mexico: 1940-2002. U.S. Geological Survey Scientific Investigations Report 2006-5287. https://pubs.usgs.gov/sir/2006/5287/index.html

Ralph PJ, Burchett MD (1998) Impact of petrochemicals on the photosynthesis of Halophila ovalis using chlorophyll fluorescence. Mar Pollut Bull 36:429-436

Ray BR, Johnson MW, Cammarata K, Smee DL (2014) Changes in seagrass species composition in northwestern Gulf of Mexico estuaries: effects on associated seagrass fauna. PLOS ONE 9:e107751

Rouhani S, Baker MC, Steinhoff S, Zhang $M$ and others (2017) Nearshore exposure to Deepwater Horizon oil. Mar Ecol Prog Ser 576:111-124

Editorial responsibility: Just Cebrian, Dauphin Island, Alabama, USA
Sandulli R, Bianchi CN, Cocito S, Morri C, Peirano A, Sgorbini S (1998) An experience of 'basilage' in monitoring the effects of the 'Haven' oil spill on some Ligurian Posidonia oceanica meadows. Oebalia 24:3-15

* Scarlett A, Galloway TS, Canty M, Smith EL, Nilsson J, Rowland SJ (2005) Comparative toxicity of two oil dispersants, superdispersant-25 and corexit 9527, to a range of coastal species. Environ Toxicol Chem 24:1219-1227

Silliman BR, van de Koppel J, McCoy MW, Diller J and others (2012) Degradation and resilience in Louisiana salt marshes after the BP-Deepwater Horizon oil spill. Proc Natl Acad Sci USA 109:11234-11239

Stout SA, Payne JR, Emsbo-Mattingly D, Baker G (2016) Weathering of field-collected floating and stranded Macondo oils during and shortly after the Deepwater Horizon oil spill. Mar Pollut Bull 105:7-22

* Tatem HE, Cox BA, Anderson JW (1978) The toxicity of oil and petroleum hydrocarbons to estuarine crustaceans. Estuar Coast Mar Sci 6:365-373

* Thorhaug A, Marcus J (1987) Oil spill cleanup: the effect of three dispersants on three subtropical/tropical seagrasses. Mar Pollut Bull 18:124-126

* Uhrin AV, Kenworthy WJ, Fonseca MS (2011) Understanding uncertainty in seagrass injury recovery: an information-theoretic approach. Ecol Appl 21:1365-1379

US EPA (United States Environmental Protection Agency) (2015) Method 8270D: semivolatile organic compounds by gas chromatography/mass spectrometry (GC/MS), Revision 4. https://www.epa.gov/sites/production/files/ 2015-12/documents/8270d.pdf (accessed on 20 January 2017)

* van der Heide T, Ekl f JS, Van Nes EH, Van der Zee EM and others (2012) Ecosystem engineering by seagrasses interacts with grazing to shape an intertidal landscape. PLOS ONE 7:e42060

Waycott M, Duarte CM, Carruthers TJB, Orth RG and others (2009) Accelerating loss of seagrasses across the globe threatens coastal ecosystems. Proc Natl Acad Sci USA 106:12377-12381

Zieman JC, Orth R, Phillips RC, Thayer GW, Thorhaug A (1984) The effects of oil on seagrass ecosystems. In: Cairns J, Buikema AL (eds) Restoration of habitats impacted by oil spills. Butterworth-Heinemann, Boston, MA, p 37-64

Submitted: February 8, 2016; Accepted: November 13, 2016 Proofs received from author(s): January 23, 2017 